\title{
Theresian and Josephine reform efforts in the regulation of the socioeconomic position of Roma in Croatia and Slavonia
}

The history of the Roma population on the Croatian area was marked by the periods in which the Roma faced the impact of the repressive and assimilatory policy of the state and local authorities towards them. The period of the reign of Maria Theresa and Joseph II was marked by such a policy, as they issued numerous decrees on Roma. The main goal of this policy was to reform the status of the Roma population by ordering them the forced sedentarization, the prohibition of their identity, e.g. their name, the use of their language and customs, doing their traditional professions and so on. As the result of such a policy, the Roma should have become the integrated part of the Habsburg society. The similar enlightened policy toward the Roma was conducted by the other European rulers as well. This paper is based on the research of the archival fonds of the Croatian State Archives, as well as the analysis of the relevant literature.

Keywords: Roma, Croatia and Slavonia, Enlightenment, reforms, Maria Theresa, Joseph II

\section{Introduction}

The Roma population has lived on Croatian area since the second half of the $14^{\text {th }}$ century and their coexistence with the non-Roma population was often characterized by intolerance and conflicts, repression and assimilation. The Habsburg authorities, together with the Croatian authorities, started conducting the policy

Danijel Vojak, Institute of Social Sciences “Ivo Pilar”, Marulićev trg 19/1, 10000 Zagreb, Croatia, E-mail: Danijel.Vojak@pilar.hr

** Neven Kovačev, Voćarska cesta 4, 10000 Zagreb, Croatia, E-mail: neven.kovacev@yahoo.com 
of assimilation and repression towards Roma already from the end of the $16^{\text {th }}$ century. Such policy reached its pinnacle in the second half of the $18^{\text {th }}$ century, during the reign of Maria Theresa and Joseph II, who undertook numerous reforms aimed at modernizing the state and the society in accordance with the ideas of the Enlightenment. Their reform tendencies encompassed the lives of Roma, as well. The aim of the paper is to analyze the Theresian and Josephine reform provisions regarding the Roma population and to ascertain the way in which they affected the legal, economic and social status of Roma in Croatia and Slavonia, as well as to compare the implementation of the mentioned reforms with the implementation of the reforms aimed at Roma in other parts of the Habsburg Monarchy and in the other European states.

\section{The history of Roma since their arrival onto the Croatian area in the second half of the $14^{\text {th }}$ century until the $18^{\text {th }}$ century}

The known historical sources state the Roma settled on the Croatian area in the second half of the $14^{\text {th }}$ century in Dubrovnik (1362) and Zagreb (1378), where they lived and worked as soldiers, servants, musicians, municipal clerks, artisans (smiths, sieve-makers, innkeepers, butchers, tanners) and merchants. ${ }^{1}$ Also, the migrations of Roma into Croatian areas are connected to the Ottoman military raids onto the areas of Lika and Krbava in the second half of the $15^{\text {th }}$ century. ${ }^{2}$ Roma settled in Pula and Šibenik and on the area of the Republic of Dubrovnik, what might suggest their gradual population of the Croatian area, especially its coastal part. ${ }^{3}$ The significant presence of the Roma population on the Croatian area might be the cause for the beginning of the regulation of the status of the Roma, conducted by the Croatian authorities from the end of the $16^{\text {th }}$ century via the decrees of the Croatian Parliament. For example, the aim of the decree of the Croatian Parliament issued in April 1593, which prescribes the Roma the tax dues, is the integration of the Roma population by embedding them into the existing system of taxation. ${ }^{4}$ From the $17^{\text {th }}$ century the issuing of the decrees by the Croatian Parliament was intensified and the policy of the repressive sedentarization and the banishment of the Roma was started. For example, the Croatian Parliament issued in 1615 the decree on the banishment of the Roma. ${ }^{5}$

\footnotetext{
1 Đurđica Petrović, "Cigani u srednjovekovnom Dubrovniku”, Zbornik Filozofskog fakulteta 13 (1976), no. 1: 124-145; Slobodan Berberski, “Romi u pretprogoniteljskoj eri”, Zadarska revija 28 (1979), no. 4: 420 .

2 Emilij Laszowski, "Povjestna crtica o ciganima”, Narodne novine 40, no. 211 (September 15, 1894): 4.

3 Petrović, "Cigani u srednjovekovnom Dubrovniku", 132; Goran Đurđević, Povijest i običaji autohtonih hrvatskih Roma - Lovara (Bjelovar: Centar savjetovanja, edukacije i kulture Roma, 2009), 20.

4 Laszowski, "Povjestna crtica o ciganima", 4.

5 Ferdo Šišić, ed., Hrvatski saborski spisi, vol. 5, Od godine 1609. do 1630. godine s dodatkom od god. 1570. do god. 1628. (Zagreb: Jugoslavenska akademija znanosti i umjetnosti, 1918), no. 79.
} 
The background of the negative change of the attitude of the Croatian authorities towards the Roma can be found in the growing antiziganism in other European countries since the middle of the $15^{\text {th }}$ century, when the authorities of other European countries started issuing antiziganist decrees, forbidding the Roma the entrance into the towns or banishing them violently from them. The leaders of such a policy towards the Roma were the German and the Spanish authorities, and their example was followed by other European authorities, e.g. Portuguese, French and English. ${ }^{6}$ The severe political and economic status of the Croatian population, pressured by the constant Ottoman danger, certainly had its negative influence on the attitude of the authorities and the domicile population towards the Roma, which were from then on perceived extremely negatively - as thieves, swindlers, sluggards and spies. Some authors claim the Roma formed a marginal group and "a potential group of the excluded" in the Croatian society, as the negative attitudes towards the Roma population were starting to emerge. ${ }^{7}$

\section{The reform regulation of the status of Roma in Croatia and Slavonia by Maria Theresa and Joseph II}

The repressive and assimilatory policy of Croatian and Habsburg authorities continued into the $18^{\text {th }}$ century. However, the territorial expansion of the Habsburg Monarchy to the areas of Sremska Mitrovica and Zemun following the 1699 Sremski Karlovci peace treaty with the Ottoman Empire had the significant impact to the Habsburg policy towards the Roma. ${ }^{8}$ The Habsburg authorities governed the newly-acquired eastern Croatian territories via the Aulic Chamber. The settlement of the newly acquired territories followed - the Roma were among the settlers. One example of conducting such a policy was the decree issued in 1695 appointing Mitrofan Popović, the vicar of the Celija Monastery, as the "director of the Rac Gypsies." His tasks included the compulsory sedentarization of the nomadic Roma between the Sava and Drava rivers. ${ }^{9}$ The Habsburg policy of appointing the specific governor (supervisor) of the Roma population was not

\footnotetext{
6 Donald Kenrick, "The Origins of Anti-Gypsyism: The Outsiders' View of Romanies in Western Europe in the Fifteenth Century", in: The Role of the Romanies: Images and Counter-images of 'Gypsies'/Romanies in European Cultures, ed. Nicolaus Saul, Susan Tebbutt (Liverpool: Liverpool University Press, 2004), 82-83; Gilad Margalit, Germany and its Gypsies: a Post-Auschwitz Ordeal (Madison: University of Wisconsin Press, 2002), 25-26; Dragica Kalember, "Kolektivna osuda skitničkog naroda Roma”, Naše teme 28 (1984), no. 7-8: 1305-1306; Laurinda Abreu, "Beggars, Vagrants and Romanies: Repression and Persecution in Portuguese Society (14th-18th Centuries)", Hygiea Internationalis: An Interdisciplinary Journal for the History of Public Health 6 (2007), no. 1: 54-64.

7 Damir Karbić, "Marginalne grupe u hrvatskim srednjovjekovnim društvima od druge polovine XIII. do početka XVI. stoljeća”, Historijski zbornik 44 (1991), no. 1: 56.

8 Ivo Goldstein, Hrvatska povijest (Zagreb: Novi Liber, 2003), 138-139.

9 Slavko Gavrilović, Srem od kraja XVII do sredine XVIII veka (Novi Sad: Filozofski fakultet, 1979), 51.
} 
unusual in the said period. For example, at the end of the $15^{\text {th }}$ century the Hungarian authorities ordered the palatine to appoint every Gypsy governor, whose title would be "egregious." 10 Such a policy was continued after the appointment of Popović as the "director" of the Roma in the eastern Croatian territories. For example, in 1738 Croatian ban Joesph Esterházy, with regarding to the complaints of the Croatian nobility on the damages and thefts perpetrated by the Roma, issued a decree ordering the subjection of the Roma to the authority of the "captain of the Gypsies" Marko Nemec; the tax was levied on the Roma - one part of which should have been paid to the captain, one part to the state, and one part to the local authorities. ${ }^{11}$

The next impetus of the more active policy of the Habsburg authorities towards the Roma was the issue of the alleged "outstanding" criminality of the Roma. The background for such a policy are the ever growing accusations of the Roma for perpetrating criminal actions, e.g. thefts of livestock and valuables, frauds, extortions and so on. The problem of solving the problems regarding the Roma population arose in front of the state and local authorities. The Roma were considered asocial parts of the society, which was in sharp opposition to the early modern concepts of the necessity of every subject to be loyal to the king, the pious and exemplary believer, i.e. "the disciplined, obedient and civilized subject." ${ }^{2}$ The archival sources on the Roma in the $18^{\text {th }}$ century often describe examples of the Roma being accused of various criminal offenses, mainly regarding horse thefts. For example, in 1742 the authorities of the town of Osijek required urgency in implementation of the decision that the Rom Miha from Valpovo should return two stolen horses, along with the cash compensation for another horse, to the two peasants from Dalj. ${ }^{13}$ Furthermore, the Roma were often accused, convicted and punished for the theft of money, cloth, farm animals and so on. ${ }^{14}$ The punishment for the mentioned crimes was a certain number of blows with a cane of whip - the punishments were prescribed on a county level..$^{15}$ In order to prevent the criminality of the Roma, some local authorities on the Croatian territory decided to banish them. For example, in June 1752 the authorities of the Virovitica County ordered the banishment of the nomadic and foreign Roma from the ter-

10 Karl Freiherr von Czoernig, Ethnographie der Oesterreichischen Monarchie, vol. 3 (Wien: Kaiserlich-koenigliche Direction der administrativen Statistik, 1857): 121-122.

11 Laszowski, "Povjestna crtica o ciganima", 4-5.

12 Ivana Jukić, Maja Katušić, "Svakodnevlje”, in: U potrazi za mirom i blagostanjem. Hrvatske zemlje u 18. stoljeću, ed. Lovorka Čoralić (Zagreb: Matica hrvatska, 2013), 233-234.

13 Ive Mažuran, ed., Rješenja Zemaljske uprave za Slavoniju 1738 - 1742 (Osijek: Historijski arhiv u Osijeku, 1970), 415-416.

14 Croatian state archives, HR-HDA-28, Križevačka županija, Acta Comitatus Crisiensis, Acta Congregationalia, box 84, file 8, No. 141; Stjepan Sršan, ed., Zapisnici općine Osijek. Prothocollum des Stadt-Raths zu Esseg od 2. 12. 1786. do 1794. g. (Osijek: Povijesni arhiv u Osijeku, 1996), 192, 202.

15 Sršan, Zapisnici općine Osijek, 192, 202. 
ritory of the county within fifteen days. Furthermore, their return to the territory of the county, as well as the further arrivals to the county of other nomadic and foreign Roma, was strictly banned. The same decree prescribed the procedure of the banishment of the Roma, which was put into the jurisdiction of the judge. ${ }^{16}$

In a certain way, the Habsburg ruler Carl VI was the precursor of the systematic policy of reforms of the status of the Roma population. In 1724 he issued a decree levying the taxes on the nomadic Roma and prescribing the obligatory registration of the Roma in Hungary. ${ }^{17}$ The reforms of the status of the Roma population conducted by Maria Theresa and Joseph II differed from all the former decrees on Roma because their policy on Roma was the first systematic attempt of regulating their legal, economic and social status. In discussing decrees on the Roma they issued, it is necessary to bear in mind the whole context of their policy, when, by issuing numerous decrees, significant attempts were made at modernizing the state and society and centralizing the state authority in accordance with the ideas of Enlightenment. ${ }^{18}$

Maria Theresa issued her first decree on the Roma in 1749: she prescribed the banishment of all the vagabond (nomadic) Roma from all the domains under her rule. ${ }^{19}$ This decree resembles similar decrees previously issued by the Habsburg authorities whose aim was to prevent the arrival of the foreign (nomadic) Roma onto the territory of the Monarchy. On the $9^{\text {th }}$ October 1783 Joseph II issued a decree which confirmed and extended the provisions previously issued by Maria Theresa. ${ }^{20}$ Since this decree quotes numerous decrees issued by Maria Theresa during the fifties, the sixties and the seventies, it offers us a great insight in her attempts to regulate the status of the Roma population. The decree issued on the $8^{\text {th }}$ November 1753 forbade the Roma to own horses, the only exception being the use of horses in agriculture. ${ }^{21}$ The Roma were to settle permanently and engage

16 Stjepan Sršan, ed., Statuti Virovitičke županije 1745. - 1792. (Osijek: Državni arhiv u Osijeku, 2008), 25-27.

17 David M. Crowe, A History of the Gypsies of Eastern Europe and Russia (New York: St. Martin's Griffin, 1996), 73.

18 The Theresian and Josephine reforms were implemented in Croatia - they were reflected in the establishment of the Royal Council, the reorganization of counties, the modernization of education, the reform of the Military Frontier, and the implementation of the religious reforms. The reforms were soon withdrawn due to the war with the Ottoman Empire, and only the Edict on Tolerance and the abolition of serfdom remained in effect: Neven Budak, "Habsburzi i Hrvati do polovice 19. stoljeća", in: Neven Budak, Mario Strecha, Željko Krušelj, Habsburzi i Hrvati (Zagreb: Srednja Europa, 2003), 98-106.

19 Angus Fraser, The Gypsies, $2^{\text {nd }}$ Ed. (Malden; Oxford; Carlton: Blackwell Publishing, 2006), 156.

${ }^{20}$ Croatian state archives, HR-HDA-32, Varaždinska županija, Acta Comitatus Varasdinensis, box 49, file 2, No. 57.

${ }^{21}$ Ibid., $\$ 2$. 
in agriculture or crafts. ${ }^{22}$ Since the Roma were not allowed to wander freely, the issuing of the passports to them was forbidden. ${ }^{23}$ Besides, the Roma were obliged to wear the clothes that resembled the clothes of the domicile population, ${ }^{24}$ Roma women were not allowed to cover their heads with scarfs and their children were not allowed to be naked in public. ${ }^{25}$ Finally, the aforementioned decree ordered the mandatory jurisdiction of the local judges over the Roma population. ${ }^{26}$ In the decree issued on the $10^{\text {th }}$ December 1761 Maria Theresa ordered that all Roma artisans who wished to join the guild of the craft they were engaged in should become the members of the guild without any obstacles. ${ }^{27}$ The mentioned decree furthermore ordered that the Roma youths of 16 and above were to be called up for military service if they were fit - the provision that was opposed by the Hungarian military officers, reluctant to draft Roma into the army. ${ }^{28}$ The decree issued on the $10^{\text {th }}$ April 1769 once again forbade the Roma to own horses, as did the decree issued on the $12^{\text {th }}$ June of the same year. ${ }^{29}$ The latter decree ordered the removal of the Roma settlements from the forests and mountains and the mandatory settlement of the Roma in lowlands. ${ }^{30}$ The decree issued on $23^{\text {rd }}$ November 1772 once again forbade the Roma to own horses ${ }^{31}$ and ordered the removal of the Roma settlements from the forests and mountains. ${ }^{32}$ Besides, it once again ordered the mandatory jurisdiction of the local judges over the Roma population, ${ }^{33}$ but also prescribed some new restrictions and regulations: it forbade use of the Romani language ${ }^{34}$ and ordered the mandatory taking away of the Roma children of four, which were to be handed over to the local population to be educated. ${ }^{35}$ The decree issued on $20^{\text {th }}$ December 1773 once again forbade the Roma to own horses ${ }^{36}$ and ordered them to engage in agriculture or crafts. ${ }^{37}$ Besides,

\footnotetext{
22 Ibid., $\$ 3$.

23 Ibid., $\$ 10$.

24 Ibid., $\$ 15$.

${ }_{25}$ Ibid., $\$ 16$.

${ }^{26}$ Ibid., $\$ 17$.

27 Ibid., $\$ 13$.

28 Fraser, The Gypsies, 156; Crowe, A History, 74.

29 Croatian state archives, HR-HDA-32, Varaždinska županija, Acta Comitatus Varasdinensis, box 49 , file 2, No. $57, \$ 2$.

${ }^{30}$ Ibid., $\$ 6$.

31 Ibid., $\$ 2$.

${ }^{32}$ Ibid., $\$ 6$.

33 Ibid., $\$ 7$.

${ }^{34}$ Ibid., $\$ 19$.

35 Ibid., $\$ 5$.

36 Ibid., $\$ 2$.

${ }^{37}$ Ibid., $\$ 4$.
} 
the aforementioned decree obliged the local judges to send monthly reports on the life and customs of Roma living on the area of their jurisdiction to the district judges. ${ }^{38}$ Such monthly reports of the local judges haven't yet been found in the archival fonds of the Croatian and Slavonian counties. Instead, several semiannual reports of the district judges sent to the county assemblies have been found. ${ }^{39}$ Finally, the decree issued on $20^{\text {th }}$ February 1775 forbade the marriage between Roma, but only in case of inability of a Roma man to prove he is capable of sustaining his wife and children by, for example, engaging in agriculture as a serf or by engaging in a craft. ${ }^{40}$

Joseph II continued the repressive and assimilatory policy of the Habsburg authorities towards the Roma. His already mentioned decree issued on the $9^{\text {th }}$ October 1783 confirmed and extended the provisions issued by Maria Theresa. In the decree, Joseph II specifically stated his aim was the sedentarization of the Roma ("so that the vagabond Gypsy race is induced to inhabiting the houses and to the assumption of the permanent status of serfs") - by doing so, the Roma will be diverted from the otiose life and they will be deprived of very opportunity of living on thefts and plundering. ${ }^{41}$ Unlike Maria Theresa's decrees on Roma, Joseph II's decree was in effect in Transylvania as well. ${ }^{42}$

\section{The implementation and the success/failure of the reforms of Maria Theresa and Joseph II on the Roma in the Habsburg Monarchy}

The reform attempts of Maria Theresa and Joseph II did not have a significant influence on the Roma in the Habsburg Monarchy. The measures regarding the sedentarization of Roma were fully implemented only in Burgenland, where the fostered Roma children were mostly successfully educated, and a large number of Roma were efficiently assimilated. ${ }^{43}$ On the other hand, in other parts of the Monarchy the success of the implementation of the said reforms was significantly

\footnotetext{
38 Ibid., $\$ 8$.

39 For example, Croatian state archives, HR-HDA-30, Severinska županija, Acta Comitatus Szeverinensis, Acta Congregationalia, box 50, file 79, No. 56; Croatian state archives, HR-HDA-30, Severinska županija, Acta Comitatus Szeverinensis, Acta Congregationalia, box 51, file 80, No. 82.

40 Croatian state archives, HR-HDA-32, Varaždinska županija, Acta Comitatus Varasdinensis, box 49 , file 2, No. 57, $\$ 1$.

${ }^{41}$ Croatian state archives, HR-HDA-32, Varaždinska županija, Acta Comitatus Varasdinensis, box 49 , file 2, No. 57 .

42 Fraser, The Gypsies, 159; Viorel Achim, The Roma in Romanian History (Budapest: CEU Press, 2004), 72 .

${ }^{43}$ Helmut Samer, "Maria Theresia and Joseph II: Policies of Assimilation in the Age of Enlightened Absolutism", 2, http://rombase.uni-graz.at//cd/data/hist/modern/data/maria.en.pdf (accessed September 10, 2017).
} 
weaker, and the reasons for the failure of the reform efforts are manifold; some scholars state the insufficient and unsystematic implementation on the local levels, first of all because of the resistance of the non-Roma population, who was unwilling to accept the coexistence with the permanently settled Roma. Besides, many nobles refused to settle the Roma on their manors - in settling the Roma they saw too large an economic risk because of the high cost of accommodating the Roma and training them for the work on the manors and the significant cost of non-Roma fosterers of the Roma children, since the costs were paid by the local authorities. ${ }^{44}$ Furthermore, to mention an example from the present-day Slovakia, the county councils often falsified the reports on the progress of the reforms on the Roma - the reason for that was the inability of the local authorities to control the implementation of the reforms. ${ }^{45}$ The settlement of the Roma was opposed by the domicile peasant population as well. The local authorities showed similar resistance because they did not have the necessary fiscal support of the higher levels of authority in conducting the reform policy towards the Roma. ${ }^{46}$

The state and other institutions failed as well - they did not have enough will and determination to thoroughly implement the reforms. One of the reasons of the failure of the reforms was the resistance of the Roma population, especially the nomadic Roma, who, faced with the implementation of the provisions on them, fled to the areas were the provisions were not so strictly implemented. The Roma refused to live in permanent houses, the "fostered" Roma children often fled away; the Roma in general maintained their old customs. ${ }^{47}$

However, a part of the Roma population settled permanently, and their children were fostered by force in the Christian families to be "reeducated" ("civilized in a Christian way")..$^{8}$ The reforms resulted in the sedentarization of the Roma especially in Burgenland. Besides, it is interesting that one such Roma colony existed in Eastern Moravia up until the 1930s, which would suggest the continuance of Maria Theresa's provisions. ${ }^{49}$

44 Will Guy, "Tko su Romi?: Romi u Čehoslovačkoj“, in: Romi. Interdisciplinarni prikaz, ed. Diane Tong (Zagreb: Ibis grafika, 2004), 21-22; David M. Crowe, "From Persecution to Pragmatism: The Habsburg Roma in the Eighteenth Century”, Austrian History Yearbook 37 (2006): 119.

45 Guy, “Tko su Romi?”, 19.

46 Ibid., 21-22.

47 Fraser, The Gypsies, 159; Guy, “Tko su Romi?”, 22.

48 Samer, "Maria Theresia and Joseph II", 2.

49 Guy, “Tko su Romi?", 19. The similar decrees were issued by the Spanish authorities, who attempted to permanently settle and assimilate the Roma violently, by forbidding them to maintain their old customs, names and language. In several German principalities and towns the Roma settlements were erected, as a precondition for their permanent settlement: Samer, "Maria Theresia and Joseph II", 2-3. 


\section{The implementation and the success/failure of the reforms of Maria Theresa and Joseph II on the Roma in Croatia and Slavonia}

In the reports of the governors to the central Habsburg and Hungarian authorities on the conditions in Slavonia, Srijem and Baranja there are many information on the implementation of the reform policy of Maria Theresa and Joseph II on the Roma. For example, Franz Stefan Engel in his report The Description of the Kingdom of Slavonia and Duchy of Srijem, while describing the conducting of the public affairs, stated that the Roma were the only population to wander freely on that territory and perpetrate criminal offences (such as horse thefts), and at the same time certain manors gave them refuge. ${ }^{50}$ Friedrich Wilhelm von Taube stated the Roma were the immigrants to the territories of Slavonia and Srijem; the authorities were currently trying to accustom them - as the "new peasants" - on the sedentary life, agriculture and paying of the taxes. ${ }^{51}$ Joseph Hajnoci stated - in his Report on the Conditions in the Srijem County, sent in 1787 to the Hungarian deputy council - that in the district of Vukovar there lived 40 Roma families. Because of the frequent horse thefts perpetrated by the Roma, he decided to forbid the local authorities the acceptance of the new Roma families without valid documents and of the Roma who own horses. He then criticized the begging of the Roma and ordered the district judges to visit the trade fairs during the religious feasts in order to punish the Roma and beggars. ${ }^{52}$ Nikola Škrlec Lomnički described in his treatise The Description of the Physical and Political Position of the Kingdom of Hungary regarding the Trade the current economic situation in Hungary and proposed a large number of suggestions, a part of which is dealing with the Roma..$^{53} \mathrm{He}$ stated the intention of the reform policy of Maria Theresa was the permanent employment of the Roma, but the reform intentions were unsuccessful because they were neither converted into a law nor thoroughly implemented. Because of this, he suggested converting the pro-

${ }_{50}$ Franz Stefan Engel, “Opis Kraljevine Slavonije i Vojvodstva Srema (I)”, translated by Vera Stojić, Zbornik Matice srpske za književnost i jezik 19 (1971), no. 2: 333; Sanja Lazanin, "Etničke i konfesionalne skupine u istočnoj Slavoniji i zapadnom Srijemu u 18. i početkom 19. stoljeća", Razprave in gradivo 56-57 (2008): 203.

${ }^{51}$ Friedrich Wilhelm von Taube, Povijesni i zemljopisni opis Kraljevine Slavonije $i$ Vojvodstva Srijema. Leipzig, 1777., 1778., translated and edited by Stjepan Sršan (Osijek: Državni arhiv u Osijeku, 2012), 54; Lazanin, "Etničke i konfesionalne skupine”, 195.

52 Slavko Gavrilović, “Bilješke Josipa Hajnocija o Srijemu 1789. godine”, Starine 53 (1966): 178-179; Lazanin, "Etničke i konfesionalne skupine", 203.

53 The treatise contains the detailed description of the general and economic situation in Hungary, with the geographic and ethnographic analyses. In it, Škrlec emphasizes the need of the stimulation of the export, building of the roads, development of the trade, manufacture and crafts, as well as the compatibility of the production and consumption with the population growth: Pál Berényi, "Djela baruna Nikole Škrlca”, in: Nikola Škrlec Lomnički 1729 - 1799, vol. 2, ed. Eugen Pusić et al. (Zagreb: Hrvatska akademija znanosti i umjetnosti; Hrvatski državni arhiv; Filozofski fakultet; Pravni fakultet, 2000), 676-681. 
visions on the Roma into a law and the strict implementation of them in order to prevent the idleness and the criminality of the Roma. ${ }^{54}$ All the above mentioned reports emphasized significant problems local authorities had in implementing the reform policy towards the Roma, especially in settling the nomadic Roma. As we have seen, some reports emphasized the problem of manors giving refuge to the Roma, which might suggest the non-functioning in implementing the policy between the state and the local authorities.

The implementation of the policy of forcing the Roma to accept the status of serfs can be observed on the local level. For example, the Great council of the Srijem County held on the $20^{\text {th }}$ of February 1764 issued a provision that all the Roma on the territory of the county should, within one month, erect permanent housings on a certain manor and accept the status of serfs. The ones who do so were not to be called Gypsies, and the ones who do not obey the provisions were not to be allowed to dwell on the territory of the county - they were to pay one florin into the county exchequer, after which they were to be banished from the territory of the county. ${ }^{55}$

The counties had to send the tables on the regulation of the Roma to the Hungarian deputy council every semester. The summary table had to be compiled, composed according to the prescribed columns - such a summary table had to be compiled from the individual tables consisting of census from the county's districts. Such a summary table was to be sent to the Hungarian deputy council together with all the individual tables (containing data from the districts). ${ }^{56}$ The counties were often late in submitting those semiannual reports and they were often admonished and urged by the Hungarian deputy council. ${ }^{57}$

On the other hand, the Hungarian deputy council, in response, notified the county councils of all the mistakes and omissions made in the mentioned reports. In doing so, the Deputy council would mention not only the mistakes made by the county authorities in compiling the tables, but also the facts that from the tables it was obvious some Roma did not live in accordance with the existing provisions, for example that some Roma children still lived together with their

\footnotetext{
${ }_{54}$ Danijel Vojak, "Iz povijesti Roma u 18. stoljeću: Nikola Škrlec Lomnički o Romima u spisima Status actualis, Projectum i Descriptio", Zbornik Odsjeka za povijesne znanosti Zavoda za povijesne i društvene znanosti Hrvatske akademije znanosti i umjetnosti 31 (2013): 197-215.

55 Ladislav Dobrica, Ivana Posedi, ed., Zapisnici sjednica Srijemske županije, vol. 2, 1760. - 1766. (Vukovar; Zagreb: Državni arhiv u Vukovaru; Hrvatski državni arhiv: 2015), no. 2012.

56 Croatian state archives, HR-HDA-30, Severinska županija, Acta Comitatus Szeverinensis, Acta Congregationalia, box 32, file 51, no. 27 (no. 3721).

57 For example, Croatian state archives, HR-HDA-32, Varaždinska županija, Acta Comitatus Varasdinensis, box 50, file 2, No. 41 et A (No. 13694); Croatian state archives, HR-HDA-32, Varaždinska županija, Acta Comitatus Varasdinensis, box 57, file 2, no. 65.
} 
parents or that Roma still wore clothes dissimilar from the clothes of the rest of the population. ${ }^{58}$

The prescribed columns of these tabular reports reflect all the information the authorities considered important and wish to know about the Roma population. With the decree issued on the $21^{\text {st }}$ January 1780 the Hungarian deputy council notified all the counties on the necessity of compiling the semiannual tabular reports on the exact and prescribed way. ${ }^{59}$

Based on such tabular reports submitted by the county authorities, the state authorities compiled the summary tables on the Roma population for the whole territory of Hungary - those summary tables contained the same columns as the tables submitted by the counties. ${ }^{60}$ In doing so, the state authorities were able to calculate the number of the Roma in Hungary in 1780 - 1783:

- $1780-33501$

- $1781-38312$

- $1782-43778$

- $1783-30251 .^{61}$

In the third volume of his Ethnographie der Oesterreichischen Monarchie, published in 1857, Karl Freiherr von Czoernig explained the lower number of Roma in 1783 in stating that those "new peasants" who had accepted the settled way of life were not considered the Roma any more, ${ }^{62}$ which would indicate a certain level of success of the authorities in implementing the reform policy towards the Roma. However, after 1783 such Roma censuses were not compiled any more. ${ }^{63}$ Of course, the mentioned censuses provide information on individual counties, including the counties in Croatia and Slavonia: ${ }^{64}$

\footnotetext{
58 For example, Croatian state archives, HR-HDA-28, Križevačka županija, Acta Comitatus Crisiensis, Acta Congregationalia, box 51, file 78, no. 26.

59 Croatian state archives, HR-HDA-30, Severinska županija, Acta Comitatus Szeverinensis, Acta Congregationalia, box 7, file 16, no. 37 (no. 492).

${ }^{60}$ Czoernig, Ethnographie, 191.

${ }^{61}$ Ibid., 189, 191.

62 Ibid., 189, footnote 3.

${ }^{63}$ Ibid., 189.

${ }^{64}$ Ibid., 190. It is interesting to note that Josip Matasović in his article "Cigani u doba terezijanstva i josefinizma", published in 1928, while citing the numerical data of the mentioned censuses of the Roma in the Croatian lands, omitted, obviously by mistake, the Varaždin County, although it is quite obvious that he used as his source the third volume of Ethnographie der Oesterreichischen Monarchie by Karl Freiherr von Czoernig: Josip Matasović, "Cigani u doba terezijanstva i josefinizma", Narodna starina, vol. 17, book 7 (December 31, 1928), no. 2: 201.
} 
Table 1. Roma in the Croatia and Slavonia in the period 1780-1783

\begin{tabular}{|c|c|c|c|c|c|}
\hline Year & $\begin{array}{c}\text { Križevci } \\
\text { County }\end{array}$ & $\begin{array}{c}\text { Požega } \\
\text { County }\end{array}$ & $\begin{array}{c}\text { Srijem } \\
\text { County }\end{array}$ & $\begin{array}{c}\text { Varaždin } \\
\text { County }\end{array}$ & $\begin{array}{c}\text { Virovitica } \\
\text { County }\end{array}$ \\
\hline $\mathbf{1 7 8 0}$ & - & - & - & - & - \\
\hline $\mathbf{1 7 8 1}$ & 102 & 166 & 407 & 38 & 648 \\
\hline $\mathbf{1 7 8 2}$ & 26 & 156 & 416 & 65 & 622 \\
\hline $\mathbf{1 7 8 3}$ & - & 186 & 471 & 53 & - \\
\hline
\end{tabular}

Source: Josip Matasović, “Cigani u doba terezijanstva i josefinizma”, Narodna starina, vol. 17, book 7, No. 2 (December 31, 1928): 201; Karl Freiherr von Czoernig, Ethnographie der Oesterreichischen Monarchie, vol. 3 (Wien: Kaiserlich-koenigliche Direction der administrativen Statistik, 1857): 190.

The incompleteness of the data gathered by the authorities is obvious - which is another proof of the weaker implementation of the reform policy towards the Roma on the local level. The Hungarian deputy council admonished the counties because of their failures to comply with the provisions, but also because of the lack of the cooperation between the counties, i.e. the lack of correspondence. ${ }^{65}$

One of the tasks of the counties was to separate the Roma children from the "dangerous parental aegis." 66 That included - according to the provision of 1772 and the before mentioned provision issued by Joseph II on the $9^{\text {th }}$ October 1783 - taking away the Roma children from their parents and the distribution of them to the non-Roma parents in the county. ${ }^{67}$ The authorities hoped the children who were not able to hang live together with their parents and relatives, which could seduce them, gradually reject - as the sources claim - their Roma nature and slowly get accustomed with the conventional way of life and - with time - transform into the good and useful citizens (Reipublicae Cives) ${ }^{68}$ In their reports on the Roma to the county councils, the district judges reported on the Roma children that could be handed over to the caretakers to be educated. ${ }^{69}$ The implementation of the provisions on taking the children away from their parents and handing them over to the non-Roma families so that they could be educated or be taught a craft can be seen in the population census of the Osijek district in 1786. The children of all five Roma families who lived in Osijek Upper Town were handed over to the

\footnotetext{
${ }_{65}$ Croatian state archives, HR-HDA-30, Severinska županija, Acta Comitatus Szeverinensis, Acta Congregationalia, box 9, file 20, no. 42 (no. 19).

${ }_{66}$ Croatian state archives, HR-HDA-31, Srijemska županija, Acta Comitatus Syrmiensis, Acta publico-politica, box 79, no. 1805 .

67 Croatian state archives, HR-HDA-32, Varaždinska županija, Acta Comitatus Varasdinensis, box 49 , file 2 , no. $57, \S 5$.

68 Croatian state archives, HR-HDA-31, Srijemska županija, Acta Comitatus Syrmiensis, Acta publico-politica, box 89, no. 2546.

${ }^{69}$ For example, Croatian state archives, HR-HDA-28, Križevačka županija, Acta Comitatus Crisiensis, Acta Congregationalia, box 57, file 90, no. 7 .
} 
non-Roma families. For some of those children it is stated they were handed over to be taught a craft. If the children who had been handed over escaped, first of all their parents would be punished for keeping the children at home, and then the children would be punished for the escape. ${ }^{70}$ The same goes for the Roma from Bijelo Brdo, ${ }^{71}$ Erdut, ${ }^{72}$ Dalj, ${ }^{73}$ Tenja ${ }^{74}$ and Hrastin ${ }^{75}$ - all their children had been taken away, and in case of the escape they were returned to their caretakers and punished. The Roma from Borovo fled away with the children who had previously been taken away from them, but they were then returned from the territory of the Military Border under military guard, after which their children were once again taken away from them. ${ }^{76}$ In Laslovo in the two Roma families there is only one child, which lives together with its teacher and attends school. ${ }^{77}$ As opposed to that, the children of all the Roma families included in the population census of the Banjin Vrh district were not taken away from their parents and distributed among the non-Roma families. ${ }^{78}$ However, those Roma were settled, they almost exclusively lived in houses, they had the inquiline status, did not engage in horse trade and did not visit fairs, so the conclusion can be made there was no reason to take their children away from them.

The prohibition of owning horses and of horse trade is one of the most important elements of the assimilatory policy towards the Roma. The implementation of the provisions on horses can be observed on the local level. The Small council of the Srijem County held on the $18^{\text {th }}$ October 1767 forbade the Roma and the beggars on the territory of the county to own horses - they had to sell all their horses until the $1^{\text {st }}$ December of that year, and if they did not do that, their horses would be taken away from them. ${ }^{79}$ The Great council held on $11^{\text {th }}$ January 1768 confirmed this decision, but ordered that it did not refer to those Roma who were, since they had rejected the vagabond way of live, called "new peasants" and offered public contributions after they had been given houses to live in..$^{80}$ On the same council the communication was read by which the Virovitica County notified the Srijem

\footnotetext{
70 Stjepan Sršan, ed., Kotar Osijek 1786. godine (Osijek: Državni arhiv u Osijeku, 2012), 88.

71 Ibid., 155.

72 Ibid., 165.

73 Ibid., 170.

74 Ibid., 178.

75 Ibid., 190.

76 Ibid., 174.

77 Ibid., 182.

78 Stjepan Sršan, ed., Baranja 1785. godine (Osijek: Državni arhiv u Osijeku, 1999), 47, 57, 63, 70, 81, 96, 105, 112, 117, 123, 129, 137, 142, 150, 155, 160, 164, 174, 192, 199, 213.

79 Ladislav Dobrica, Ivana Posedi, ed., Zapisnici sjednica Srijemske županije, vol. 3, 1767. - 1771. (Vukovar; Zagreb: Državni arhiv u Vukovaru; Hrvatski državni arhiv: 2016), no. 610.

${ }^{80}$ Ibid., no. 622.
} 
County it had ordered the same provision on the Great council held on the $16^{\text {th }}$ December 1767; this provision did not refer to the permanently settled Roma which were subject to the burden of the contribution - these Roma might travel with their horses with valid passports. ${ }^{81}$

The decrees of the Hungarian deputy council often mentioned the Roma who live in forests, at the feet of the mountains and on the mountains as those whose regulation was the most necessary. ${ }^{82}$ Those Roma were to be removed from there and they were to be forced to settle onto the plains and to build themselves the houses in a row, just as other peasants did. ${ }^{83}$ The groups of foreign Roma arriving from Poland or Transylvania were to be stopped so that they could not grab a chance for spreading and perpetrating public offences. Their leaders were to be interrogated in detail from where they had come, with what passports, which way they had entered Hungary, which counties they had crossed, where they had tarried and for how long and what they had been doing. In case they perpetrated some offences, they were to be appropriately punished, for example their passports were to be taken away from them. Finally, they were to be sent to the places of their former residence, with prior agreement with the neighboring jurisdictions. In case of need, it was necessary to provide the Hungarian deputy council with the requested information, attaching thereunto written interrogation records and the passports taken away from the Roma.$^{84}$ In the mentioned period, similar provisions were issued regarding the regulation of vagabonds and beggars. ${ }^{85} \mathrm{In}$ that regard, it is important to note that in the early modern period - until the end of the $18^{\text {th }}$ century - the notion of Roma was not unambiguously defined - for example, the vagabonds, beggars and similar marginal groups could be identified as the Roma. ${ }^{86}$

The giving of the leave for the Roma serving the military was also regulated. The Roma soldiers were not to be given the leave unless they served in the military for six consecutive years. Besides, there had to be no doubt on the rectitude of their lives. In case the satisfactory occupancy of the military legions permitted it, there was a possibility of giving the leave to those Roma who wished to live from

\footnotetext{
81 Ibid., no. 643.

82 Croatian state archives, HR-HDA-31, Srijemska županija, Acta Comitatus Syrmiensis, Acta publico-politica, box 88, no. 2497.

${ }_{83}$ Croatian state archives, HR-HDA-32, Varaždinska županija, Acta Comitatus Varasdinensis, box 49 , file 2 , no. $57, \$ 6$.

${ }^{84}$ Croatian state archives, HR-HDA-30, Severinska županija, Acta Comitatus Szeverinensis, Acta Congregationalia, box 9, file 20, no. 42 (no. 19).

85 Sršan, Statuti Virovitičke županije, 25-27.

86 Stephan Steiner, Rückkehr unerwünscht: Deportationen in der Habsburgermonarchie der Frühen Neuzeit und ihr europäischer Kontext (Vienna; Cologne; Weimar: Böhlau Verlag, 2014), 43.
} 
agriculture, crafts or day-labor. ${ }^{87}$ The Roma soldiers were to be given the leave only if they attested their means of support. ${ }^{88}$

The settling of the Roma in Požega was the consequence of the reform efforts of Maria Theresa, i.e. the policy of sedentarization of the Roma population. In the $18^{\text {th }}$ century there was a "Gypsy street" (Ciganski sokak) there. From 1761 until 178623 Roma lived in Požega. In 1882 that street was renamed German street (Njemačka ulica). ${ }^{89}$

The event of 1782, when a group of Roma was accused of cannibalism in the Hont County, in what is now Slovakia, had its aftermath in Croatia and Slavonia, too. For example, the Srijem County was obliged to accept the seven children of the Roma that were - after they were accused of the mentioned crime of cannibalism and theft - executed or banished onto the Ottoman territory. The intention of the authorities was to exterminate the sole memory of that crime, although the investigation showed the crime in question was just a theft, without cannibalism. The extermination of the sole memory of the crime was to be achieved by relocating the children of the perpetrators of that crime into the counties as remote as possible from the Hont County, including the counties in Croatia and Slavonia. These children were to be handed over to the Roman Catholic peasants or artisans to be educated, in a way that each town or each manor was to accept only one child. ${ }^{90}$ The decree of the Hungarian deputy council issued on the $22^{\text {nd }}$ December 1783 shows us that some of the children form the Hont County were relocated into the Varaždin County; issuing this decree, the Hungarian deputy council admonished the Varaždin County for not submitting the report on whether the children from the Hont County - relocated to the territory of the Varaždin County - were handed over to the Roman Catholic peasants. ${ }^{91}$

It seems that in the mid-1780s the authorities intended to relocate some Roma to the territory of the Littoral district in the Severin County; the district judge of that district notified the council of the Severin County that the planned intention is not implementable because of the excessive population of that district. ${ }^{92}$

\footnotetext{
${ }^{87}$ Croatian state archives, HR-HDA-32, Varaždinska županija, Acta Comitatus Varasdinensis, box 49, file 2, no. 41 et $\mathrm{E}$ (no. 11687).

${ }_{88}$ Croatian state archives, HR-HDA-32, Varaždinska županija, Acta Comitatus Varasdinensis, box 49, file 2, no. 57 et A (no. 10787).

${ }^{89}$ Julije Kempf, Požega. Zemljopisne bilješke iz okoline i prilozi za povijest slob. i kr. grada Požege i Požeške županije [Požega: Štamparija "Hrvatske tiskare i knjižare", 1910 (Reprint: Požega; Jastrebarsko: Matica hrvatska, Ogranak Požega; Naklada Slap, 1995)]: 687-688.

90 Croatian state archives, HR-HDA-31, Srijemska županija, Acta Comitatus Syrmiensis, Acta publico-politica, box 89, no. 2546 .

${ }_{91}$ Croatian state archives, HR-HDA-32, Varaždinska županija, Acta Comitatus Varasdinensis, box 50 , file 2 , no. 2 .

92 Croatian state archives, HR-HDA-30, Severinska županija, Acta Comitatus Szeverinensis, Acta Congregationalia, box 31, file 50, no. 33 .
} 
In 1787 the Habsburg Monarchy entered the new war against the Ottomans, which has not been in its favor since its inception..$^{33}$ The situation of warfare also affected the policy towards the Roma - next year, a decree was issued that permitted the immigration of the Roma from the Ottoman territory. The Roma families who emigrated from the Ottoman territory had to be taken care of in a way harmless to the public safety. They were to be treated with every kindness and were to be given every possible opportunity to earn money to maintain themselves. However, the special attention had to be made towards those Roma immigrants who had previously been banished to the Ottoman territory. ${ }^{94}$

\section{Conclusion}

The Roma population populated the Croatian areas from the second half of the $14^{\text {th }}$ century, and from then on their coexistence with the non-Roma population was mostly marked by conflicts. This is the context in which it is necessary to analyze the status of the Roma in Croatia and Slavonia in the second half of the $18^{\text {th }}$ century, during the reign of Maria Theresa and Joseph II. Bearing in mind the enlightened ideas of the need of the humanitarian role of the state and of the progress of the state, as well as cameralistic ideas of the state that has to conduct a single economic policy intended to increase of the income of the state by fostering the prosperity of the whole population, the enlightened rulers strove in some European countries to reform the status of the Roma population. Such a policy included the attempts of the repressive integration of the Roma into the existing society, which, in fact, meant the total assimilation of the Roma population. Maria Theresia - and later Joseph II - issued many provisions ordering compulsory sedenterization, tending to prevent the vagabondage of the nomadic Roma groups. Furthermore, the mentioned provisions on the Roma had an aim of suppressing the identity of the Roma as the separate (minority) group by forbidding them to use their language, to maintain their customs and to engage in their traditional occupations, and by taking away their children, which were to be handed over to the non-Roma Christian families. Such a policy of Maria Theresa and Joseph II was implemented on the Croatian territory, too, on which the contemporaries of these events, such as Nikola Škrlec Lomnički, testify. The reasons of the failure of the mentioned policy can be seen in the insufficient cooperation of the state and local authorities and the domicile population, as well as the resistance of the Roma population.

\footnotetext{
93 Maja Katušić, "Pregled političkih zbivanja", in: U potrazi za mirom i blagostanjem. Hrvatske zemlje u 18. stoljeću, ed. Lovorka Čoralić (Zagreb: Matica hrvatska, 2013), 20.

94 Croatian state archives, HR-HDA-34, Zagrebačka županija, Acta Comitatus Zagrabiensis, Publico politica, box 41, no. 2636 .
} 


\section{Archival sources}

Croatia - Croatian State Archives, Zagreb - HR-HDA-28, Križevačka županija Acta Comitatus Crisiensis - Acta Congregationalia

Croatia - Croatian State Archives, Zagreb - HR-HDA-30, Severinska županija Acta Comitatus Szeverinensis - Acta Congregationalia

Croatia - Croatian State Archives, Zagreb - HR-HDA-31, Srijemska županija Acta Comitatus Syrmiensis - Acta publico-politica

Croatia - Croatian State Archives, Zagreb - HR-HDA-32, Varaždinska županija - Acta Comitatus Varasdinensis

Croatia - Croatian State Archives, Zagreb - HR-HDA-34, Zagrebačka županija Acta Comitatus Zagrabiensis - Publico politica

\section{Published sources}

Dobrica, Ladislav; Posedi, Ivana, eds. Zapisnici sjednica Srijemske županije. Vol. 2. 1760. - 1766. Vukovar; Zagreb: Državni arhiv u Vukovaru; Hrvatski državni arhiv, 2015.

Dobrica, Ladislav; Posedi, Ivana, eds. Zapisnici sjednica Srijemske županije. Vol. 3. 1767. - 1771. Vukovar; Zagreb: Državni arhiv u Vukovaru; Hrvatski državni arhiv, 2016.

Engel, Franz Stefan. “Opis Kraljevine Slavonije i Vojvodstva Srema (I)”. Translated by Vera Stojić. Zbornik Matice srpske za književnost i jezik 19 (1971), no. 2: 289-356.

Mažuran, Ive, ed. Rješenja Zemaljske uprave za Slavoniju 1738 - 1742. Osijek: Historijski arhiv u Osijeku, 1970.

Sršan, Stjepan, ed. Zapisnici općine Osijek. Prothocollum des Stadt-Raths zu Esseg od 2. 12. 1786. do 1794. g. Osijek: Povijesni arhiv u Osijeku, 1996.

Sršan, Stjepan, ed. Baranja 1785. godine. Osijek: Državni arhiv u Osijeku, 1999.

Sršan, Stjepan, ed. Statuti Virovitičke županije 1745. - 1792. Osijek: Državni arhiv u Osijeku, 2008.

Sršan, Stjepan, ed. Kotar Osijek 1786. godine. Osijek: Državni arhiv u Osijeku, 2012.

Šišić, Ferdo, ed. Hrvatski saborski spisi. Vol. 5. Od godine 1609. do 1630. godine s dodatkom od god. 1570. do god. 1628. Zagreb: Jugoslavenska akademija znanosti i umjetnosti, 1918. 
Taube, Friedrich Wilhelm von. Povijesni i zemljopisni opis Kraljevine Slavonije i Vojvodstva Srijema. Leipzig, 1777., 1778. Translated and edited by Stjepan Sršan. Osijek: Državni arhiv u Osijeku, 2012.

\section{Literature}

Abreu, Laurinda. "Beggars, Vagrants and Romanies: Repression and Persecution in Portuguese Society (14 $4^{\text {th }}-18^{\text {th }}$ Centuries)". Hygiea Internationalis: An Interdisciplinary Journal for the History of Public Health 6 (2007), no. 1: 41-66.

Achim, Viorel. The Roma in Romanian History. Budapest: CEU Press, 2004.

Berberski, Slobodan. “Romi u pretprogoniteljskoj eri”. Zadarska revija 28 (1979), no. 4: 415-422.

Berényi, Pál. “Djela baruna Nikole Škrlca”. In: Nikola Škrlec Lomnički 1729 - 1799, vol. 2, ed. Eugen Pusić, Vladimir Stipetić, Josip Kolanović, Miljenko Pandžić, Željko Pavić, Stjenko Vranjican, 641-688. Zagreb: Hrvatska akademija znanosti i umjetnosti; Hrvatski državni arhiv; Filozofski fakultet; Pravni fakultet, 2000.

Budak, Neven. "Habsburzi i Hrvati do polovice 19. stoljeća”. In: Neven Budak, Mario Strecha, Željko Krušelj, Habsburzi i Hrvati, 5-127. Zagreb: Srednja Europa, 2003.

Crowe, David M. A History of the Gypsies of Eastern Europe and Russia. New York: St. Martin's Griffin, 1996.

Crowe, David M. "From Persecution to Pragmatism: The Habsburg Roma in the Eighteenth Century." Austrian History Yearbook 37 (2006): 99-120.

Czoernig, Karl Freiherr, von. Ethnographie der Oesterreichischen Monarchie. Vol. 3. Wien: Kaiserlich-koenigliche Direction der administrativen Statistik, 1857.

Đurđević, Goran. Povijest i običaji autohtonih hrvatskih Roma - Lovara. Bjelovar: Centar savjetovanja, edukacije i kulture Roma, 2009.

Fraser, Angus. The Gypsies. $2^{\text {nd }}$ Ed. Malden; Oxford; Carlton: Blackwell Publishing, 2006.

Gavrilović, Slavko. Srem od kraja XVII do sredine XVIII veka. Novi Sad: Filozofski fakultet, 1979.

Goldstein, Ivo. Hrvatska povijest. Zagreb, Novi Liber, 2003.

Guy, Will. “Tko su Romi?: Romi u Čehoslovačkoj”. In: Romi. Interdisciplinarni prikaz, ed. Diane Tong, 13- 66. Zagreb: Ibis grafika, 2004.

Jukić, Ivana; Katušić, Maja. "Svakodnevlje”. In: U potrazi za mirom i blagostanjem. Hrvatske zemlje u 18. stoljeću, ed. Lovorka Čoralić, 233- 256. Zagreb: Matica hrvatska, 2013. 
Kalember, Dragica. "Kolektivna osuda skitničkog naroda Roma”. Naše teme 28 (1984), no. 7-8: 1296-1312.

Karbić, Damir. "Marginalne grupe u hrvatskim srednjovjekovnim društvima od druge polovine XIII. do početka XVI. stoljeća”. Historijski zbornik 44 (1991), no. 1: 43-76.

Katušić, Maja. "Pregled političkih zbivanja”. In: U potrazi za mirom i blagostanjem. Hrvatske zemlje u 18. stoljeću, ed. Lovorka Čoralić, 3-26. Zagreb: Matica hrvatska, 2013.

Kempf, Julije. Požega. Zemljopisne bilješke iz okoline i prilozi za povijest slob. i kr. grada Požege i Požeške županije. Požega: Štamparija "Hrvatske tiskare i knjižare", 1910 (Reprint: Požega; Jastrebarsko: Matica hrvatska, Ogranak Požega; Naklada Slap, 1995).

Kenrick, Donald. “The Origins of Anti-Gypsyism: The Outsiders' View of Romanies in Western Europe in the Fifteenth Century". In: The Role of the Romanies: Images and Counter-images of 'Gypsies'/Romanies in European Cultures, ed. Nicolaus Saul, Susan Tebbutt, 79-84. Liverpool: Liverpool University Press, 2004.

Lazanin, Sanja. "Etničke i konfesionalne skupine u istočnoj Slavoniji i zapadnom Srijemu u 18. i početkom 19. stoljeća”. Razprave in gradivo 56-57 (2008): 190-211.

Laszowski, Emilij. "Povjestna crtica o ciganima”. Narodne novine 40, no. 211 (September 15, 1894): 4-5.

Margalit, Gilad. Germany and its Gypsies: a Post-Auschwitz Ordeal. Madison: University of Wisconsin Press, 2002.

Matasović, Josip. "Cigani u doba terezijanstva i josefinizma”. Narodna starina, vol. 17, book 7, no. 2 (December 31, 1928): 200-201.

Petrović, Đurđica. “Cigani u srednjovekovnom Dubrovniku”. Zbornik Filozofskogfakulteta 13 (1976), no. 1: 123-158.

Samer, Helmut. "Maria Theresia and Joseph II: Policies of Assimilation in the Age of Enlightened Absolutism". http://rombase.uni-graz.at//cd/data/hist/modern/data/maria.en.pdf (accessed September 10, 2017).

Steiner, Stephan, Rückkehr unerwünscht: Deportationen in der Habsburgermonarchie der Frühen Neuzeit und ihr europäischer Kontext. Vienna; Cologne; Weimar: Böhlau Verlag, 2014.

Vojak, Danijel. “Iz povijesti Roma u 18. stoljeću: Nikola Škrlec Lomnički o Romima u spisima Status actualis, Projectum i Descriptio". Zbornik Odsjeka za povijesne znanosti Zavoda za povijesne i društvene znanosti Hrvatske akademije znanosti i umjetnosti 31 (2013): 197-215. 


\section{Danijel Vojak*}

Neven Kovačev ${ }^{* *}$

\section{Marijaterezijanska i jozefinska reformska nastojanja u reguliranju društveno-ekonomskog položaja Roma u Hrvatskoj i Slavoniji}

\section{Sažetak}

Povijest romske populacije na hrvatskom prostoru obilježila su razdoblja u kojima su se Romi suočili s utjecajem represivne i asimilacijske politike države i lokalnih vlasti. Obzirom da su donijeli brojne odredbe o položaju Roma, razdoblje vladavine Marije Terezije i Josipa II. obilježeno je upravo takvom politikom. Glavni cilj donesenih odredbi, kojom su Romi trebali postati integrirani dio društva unutar granica Habsburške Monarhije, bila je reformacija statusa romske populacije kroz provođenje prisilne sedentarizacije te zabranu isticanja i korištenja romskog identiteta, imena, jezika, običaja te obavljanja tradicionalnih zanimanja. Sličnu prosvijećenu politiku prema Romima provodili su i drugi europski vladari. Ovaj se rad temelji na istraživanju arhivskih fondova Hrvatskog državnog arhiva, kao i na analizi relevantne literature.

Ključne riječi: Romi, Hrvatska i Slavonija, prosvjetiteljstvo, reforme, Marija Terezija, Josip II.

\footnotetext{
Danijel Vojak, Institut društvenih znanosti "Ivo Pilar”, Marulićev trg 19/1, 10000 Zagreb, Republika Hrvatska, E-mail adresa: Danijel.Vojak@pilar.hr

** Neven Kovačev, Voćarska cesta 4, 10000 Zagreb, Republika Hrvatska, E-mail adresa: neven.kovacev@yahoo.com
} 